\title{
Character Building Methods Elementary School Teacher in Jakarta Region
}

\author{
Yufiarti \\ Faculty of Psychology \\ Universitas Negeri Jakarta \\ Jakarta, Indonesia \\ yufiarti@unj.ac.id
}

\author{
Taufik Rihatno, Sri Nuraini \\ Faculty of Sport Science \\ Universitas Negeri Jakarta \\ Jakarta, Indonesia \\ taufikrihatno@unj.ac.id
}

\author{
Miftachus Sholikah \\ Faculty of Early childhood \\ Universitas Negeri Jakarta \\ Jakarta, Indonesia \\ miftachussholikah@unj.ac.id
}

\begin{abstract}
Character building is important to develop children potential development in elementary school. The basic foundation in Indonesia will be a very strong nation in all sectors in 2045 or 100 years after its independence day. This research provides information about the methods used by teachers to build elementary school students character in Jakarta. The research used qualitative data which were obtained from teachers based on interview and observation. Analysing data used NVIVO. The results show that the character building was conducted through various methods such as lecturing, group session, role-play, conditioning, modeling, telling story and dialogue. This research has offered an effective character education program using various methods.
\end{abstract}

Keywords - character building; elementary school teacher; various methods

\section{INTRODUCTION}

Education has been considered as the centre of excellence in preparing human's excellent characters. Character education has been a part of education in Indonesia beginning early in the nation "history". It also important for face global challenges [1]. Teacher integrate the character education through the curriculum [2].

There are four principles used to develop education character stated by the Ministry of Education and Culture (2010: 11-14).

- Sustainable in the education context. This means that character education is a long process of cultivating characters started from the beginning until the end of education process at schools.

- Integrated in all subjects, self-development, and education culture. This means that the process of character development is done through every single subject at school, every extracurricular program, and co-curricular program based on the Curriculum Content Standard.

- Value is neither caught nor taught, it is learned. This means that the value of character is not teaching materials. But, this is something to learn by students. The students are the subject of learning. Therefore, teachers do not need to change the teaching materials but provide students with chances and possibilities to learn and to internalize character education.

- Active and interesting learning process. This means that character education process puts students as the subject of learning. The learning atmosphere should be lively, active, and interesting.

A variety of studies have concluded the importance of sincerity, discipline, tolerance and respectful behavior of children toward teacher and elderly person. Character education refers to the formal, regular lessons provided in school that adhere to a relevant curriculum to promote students' moral character [3]. As such, character education stresses the development of students' moral character as a whole, which is more than cognitive development in moral reasoning. Character education therefore prizes the development of students' emotions and values in a morally and socially competent way [4].

Some character education standards used to direct education are as follows; (1). Promoting the values of ethics as the foundation of character education. (2). Identifying character comprehensively, this covers idea, feeling, and action. (3). Using practice and effective approach to cultivate and build character. (4). Creating a caring educational environment. (5). Giving chances to students to express their ideas and behave. (6). Developing appropriate curriculum which supports character education. (7). Cultivating students' motivation. (8). Sharing the responsibility to all members of schools for the sake of education character. (9). Building good leadership in 
character education. (10). Building cooperation and good relationship with family and people around the schools. (11). Evaluating the school character, academics [1].

The success of education character can be influenced by the technique or approach used in the teaching and learning process. Suparno et al in [1] explained that there are three models of teaching and learning in character education such as:

- Integrating Model, This can be done through cooperation between teachers and some other people out of schools. This model leads to a shared and cooperative activity among schools academics and people around the schools. In addition, the students will be overwhelmed by character education at school and then practice it out of school.

- Monolithic Model, This means that the teacher of character education should develop curriculum, syllabus, lesson plan and teaching Media to teach character education subject to students. This model is delivered to students clearly. However, this means that the value learned by students is dependent on the curriculum design which means artificial.

- Extracuricular Model, Character education can also be done out of school hours. This usually focuses more on some activities out of school and then followed by discussion after the activities.

Character development at school gets to be done through lecturing, group session, role-play, conditioning, modeling, telling story and dialogue. There is a very basic character and needs to be developed by elementary school age child is: sincerity, grateful tofu, order, thoughtful attention, good at heart, accountability, excused, care, timely, patient, thrifty/conscientious, tolerance (price), and politeness.

\section{METHOD}

Qualitative research methods by using a questionnaire is aimed to learn details on the subject [5]. The research used qualitative data which were obtained by teachers based on interview and observation. The participant consist 4 teachers elementary school. Analysing data used Nvivo version 9.

\section{RESULT AND DISCUSSION}

Based on the results of interviews with teachers at the primary school, it is found that character education has been implemented in every school. Including all the lessons also instill a character in the students, it's just subject civic education, Religion and Bahasa Indonesia that directly affect the students. This was disclosed by Ibu N guardian of grade 3B elementary education Bojong Rawalumbu $\mathrm{X}$ Bekasi as following:

"In the lesson of civic education teacher teach the values in the community by using examples. If the method that teacher utilizes with in a general way. Examples: group discussion, practical exercise such as keeps clean classroom".
Further explained by teacher state elementary school Bojong Rawalumbu X Bekasi.

"In the KDP lesson the mother teaches about the rules that apply in the community, keeps the students making examples of the rules. Whereas in the subjects Indonesian language teaches students to read and make sentences with good intonation and pronunciation".

In elementary school Bojong Rawalumbu X Bekasi there is also a canteen of honesty, where the students are allowed to take the desired snacks without any servant serving, so the students are required to behave honestly that ultimately can form the character of honest students.

"Learning this character cannot be done quickly and simultaneously. Learning about positive characters in children should slowly and gradually not be directly. The way it should be with the easy to understand by the child, the teacher must choose a good technique, which is varied and liked by children. For the learning of this character to be effective and right on the target". (Mrs I teacher elementary school 04 Rawa Sari Jakarta)

In addition, each School requires students to come to school on time and give a light warning if there are students who are late. This is so that students are accustomed to appreciate the time. Schools also familiarize their students to say hello and honor older people and peers. As done by public elementary school teacher 02 Ceger Bekasi: Mrs. E said:

"The school's way of improving character in addition to the direct approach by teachers is usually that schools also conduct activities such as class pickets to cultivate a sense of responsibility and love for cleanliness. There is also a creativity competition that can develop the creativity that every student has." (E \& nbsp elementary education 02 ceger Bekasi)".

The way that is done by elementary school 02 Ceger and elementary school Bojong Rawalumbu X Bekasi reminds us that, the influence of learning process on character formation. Help students learn virtue or develop different characters by providing a conducive environment in school. It means learning values of virtue involve awareness, beliefs and feelings, in addition to logic. Therefore, the learning process in order to develop the character needs to be developed creatively so that a student can learn through the various mental dimensions that exist in him. There are many ways that can be done and one way can be combined in other ways, depending on the context at hand.

If the method used by mother in general, the mother used to give the material in advance to the protege of the mother, usually the mother also makes a group for children to discuss with their friends. But for some learning that can be practiced, mothers usually invite children to practice it directly. Like keeping the cleanliness, mothers prefer children who maintain cleanliness by holding a class picket. (W, elementary school 01 Menteng Jakarta)

Here Ibu E started with understanding while explaining the material, after which the students made various groups to discuss various phenomena in the community. But in terms of 
cleanliness and set the layout of the schoolroom directly practice only. This way students can experience firsthand many good habits. This is exactly what the NS did.

To develop a positive character, teachers should set concrete examples of children, because children cannot yet imagine things properly and appropriately. As a teacher, we must be very patient in educating our children, teaching good things that are not only spoken but also carried out. For example I teach about class cleanliness, then I as a role model should not throw garbage carelessly anyway, so that learners can imitate what I do. It teaches religious things that are a very good foundation and are very useful in the development of positive characters. (Ibu N S, elementary school 01 Utan Kayu Jakarta Timur)

In closing, the answer from Mrs. Nani Sumarni has represented what has been done by other teachers in various elementary school in Jakarta, Bogor and Bekasi. Which can be summarized in the following sigure 1 :

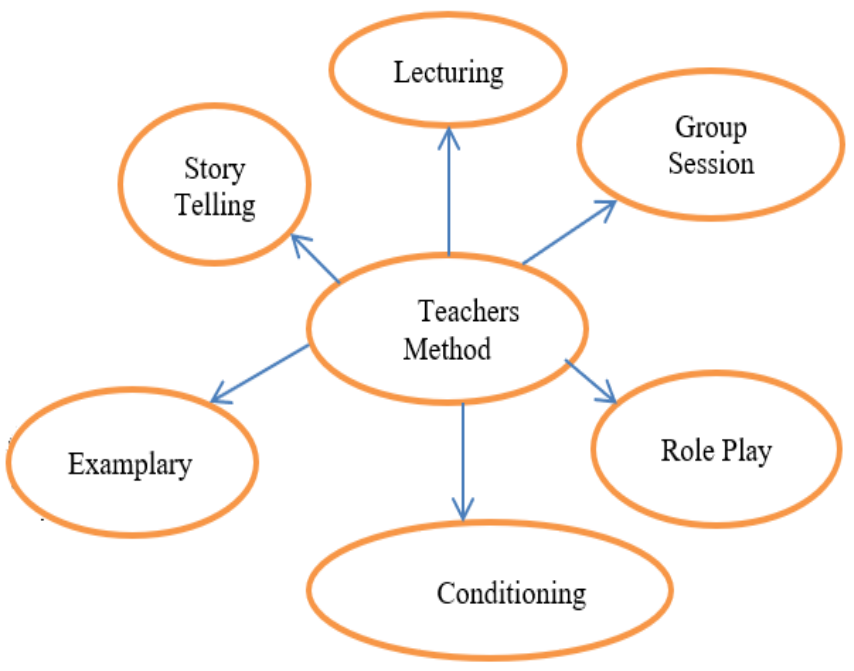

Fig. 1. Master's method in developing character.

From the picture above can be concluded that the teacher did various ways of growing the character on the students. Most teachers still using lectures and dialogues, playing roles, habituation and more important examples. However, to cultivate the significance of each character has not been maximally done by the teacher. This attempt is done thoroughly (holistic) and sustainable. The key to character education is to internalize the virtue of the student so that he can face the challenges of life in the future. Virtue is good habits from the mind, hearts, and actions that make us can choose and do well.

Furthermore, this result accord teaching character using various methods, the teacher used a role model approach for values education. [6]. For other research stated that the teacher played a significant role in shaping the character of students along with the parents, through self-assessment [7]. The benefit of character education for students is something that should not be underestimated. This is because character is a way of thinking and behaving by someone in contact with others $[8,9]$. By understanding the benefits of character education for students, it will also benefit those around them [10]. Character education will also have an impact on the child's own life. Because it will inhibit the potential to become a learned and intelligent student in attitude [11].

\section{CONCLUSION}

Character building was conducted through various methods such as lecturing, group session, role-play, conditioning, modeling, telling story and dialogue. This research has offered an effective character education program using various methods. Character building was conducted through various methods such as lecturing, group session, role-play, conditioning, modeling, telling story and dialogue. This research has offered an effective character education program using various methods

\section{REFERENCES}

[1] R. Fathur, A. Syaifudin, and Yuliati. "Character Education for Golden Generation 2045 (National Character Building for Indonesian Golden Years)." Procedia - Social and Behavioral Sciences 141: 1161-65. 2014.

[2] Fahmy, Rahmi, N. Bachtiar, R. Rahim, and M. Malik. "Measuring Student Perceptions to Personal Characters Building in Education: An Indonesian Case in Implementing New Curriculum in High School." Procedia - Social and Behavioral Sciences 211: 851-58. 2015.

[3] Berkowitz, M. W., and Bier, M. C., "Conducted." American Quarterly. 21(1): 125-33. 2015.

[4] Cheung, C. kiu, and T. Y. Lee, "Improving Social Competence through Character Education.” Evaluation and Program Planning 33(3): 255-63. 2010 .

[5] Turan, B., "The Opinions Of Teachers On The Use Of Cartoon Character In The Mathematics Lesson." Procedia - Social and Behavioral Sciences 141: 1386-91. 2014.

[6] Y. Sahinkayasi, O. Kelllect. "Elementary School Teachers ' Views on Values Education." procedia 93: 116-20. 2013.

[7] Ülger, Mehmet, S. Yi, and O. Ercan. "Secondary School Teachers Beliefs On Character Education Competency." 131(4310): 442-49, 2014.

[8] Agung, L. "Character Education Integration in Social Studies Learning." Historia: Jurnal Pendidik dan Peneliti Sejarah 12(2): 305-6. 2018.

[9] Lewis, Mc Robert, and V. Ponzio. "Character Education as the Primary Purpose of Schooling for the Future." Jurnal Ilmiah Peuradeun 4(2): 137-46. 2016.

[10] Bacia, Ewa, and A. Ittel. "Education to Thrive in a Heterogeneous and Democratic Society-A Task for Citizenship and Character Education? Results of Case Studies in Three Berlin Schools." JSSE-Journal of Social Science Education 16(3): 137-46. 2017.

[11] Freeman, G. G., "The Implementation of Character Education and Children's Literature to Teach Bullying Characteristics and Prevention Strategies to Preschool Children: An Action Research Project." Early Childhood Education Journal 42(5): 305-16. 2014. 